\title{
The Influence of Certification and Profession Commitment Toward Teachers' Performance at Madrasah Tsanawiyah Samarinda
}

\author{
Sitti Aminah ${ }^{1}$, PM. Labulan², Maruf Akbar ${ }^{3}$ \\ ${ }^{1}$ Student Master of Education, Mulawarman University, East Kalimantan, Indonesia \\ ${ }^{2}$ Faculty of Education and Teacher Training, Mulawarman University, East Kalimantan, Indonesia \\ ${ }^{3}$ Faculty of Education and Teacher Training, Jakarta State University, Indonesia \\ na_minah12@yahoo.com
}

\begin{abstract}
The aims of this study is to test the performance results of teachers who have been certified with teachers who have not been certified with 2 × 2 factorial design. Data collection using the teacher performance questionnaire instrument and teacher commitment professions instrument. Instrument validation was performed using Product Moment Test with tTest, and Readability Test using Spearman Brown and Alpha. Data were analyzed by two-way ANAVA, normality test of data using Lilliefors test while homogeneity test data using Bartlett Test and $F$ test. Comparative data test between cells using $T$ Dunnet test and Turkey Test. so that the conclusion is obtained: (1) Performance of teachers who have been certified in general is higher than the performance of teachers who have not certified. (2) There is an interaction between certification status and teacher professional commitment to teacher performance. (3) In teachers who are professionally committed, certified teachers have higher performance than uncertified teachers. (4) In teachers with low profession commitment, certified teachers have lower performance than uncertified teachers.
\end{abstract}

Keywords-certification, professional commitment, teacher performance

\section{INTRODUCTION}

Education is one of the most strategic and effective ways in building the quality of human resources and can improve the dignity of human beings, even the progress or retreat of a country seen from the progress of education and technology. Teachers as one of the pillars that spearhead the progress of education becomes a very important thing to note because in the hands of teachers of the fate of the nation's next generation is laid. Therefore, a teacher should be able to exert all the skills and skills that he possesses in carrying the noble task. It is undeniable that the teacher as humans who on their shoulders placed noble duties in building human resources of noble character, skilled and broad-minded require the attention of various parties principally government so that teachers can perform their duties with pleasure and professional.

Teacher certification is the process of giving educator certificates to teachers who are assigned as classroom teachers, subject teachers, counseling and guidance teachers, and teachers who are appointed in the supervisory unit of the education unit. Teacher certification is the process of awarding teacher certificates for teachers who have met the teacher's competency standards. Teacher certification aims to: (1) determine teacher's eligibility in performing tasks as a learning agent and realize the goals of national education; (2) improve the process and quality of educational outcomes; (3) improve teacher dignity; (4) increase teacher professionalism; improve teachers' welfare.

Related with teacher certification in the effort to improve the quality and welfare of teachers, according to Muslich, in some developed countries have implemented it first certification such as America through an independent body of The American Association of Collages for Teacher Education (AACTE) [5]. Teacher certification was also applied in Asian countries such as China, Philippines and Malaysia. While the Japanese government believes that the progress of the nation must start from the world of education, with the requirement to have qualified teachers and after enacted teacher certification in this country the teachers earn a relatively large income.

The performance of a teacher is very much determine the high or low learning outcomes so that performance is a factor that needs to be considered to always be improved in order to improve the quality of education. This is in line with Robin's opinion that success in doing something is determined by performance $[9,10]$. Performance is the result of an activity or work [7], while Bernardin and Russell in Ruky suggest "Performance is The Record of Outcome Produced on Specified Period" [8]. The process by which the organization evaluates or assesses the performance of employees. The same thing by Prawiro Suntoro in Pabundu Tika states that performance is the work that can be achieved by a person or group of people within an organization in order to achieve organizational goals within a certain period [11].

Furthermore Bowin and Harvey stated that Performance may be defined as the Accomplishment of an employee or manager assigned duties and the outcomes produced on a job function or activity during the specified time period [3]. In the definition there is a meaning that performance is related to achievement factor, because it is related to seriousness in work. 
Performance words also refer to the work in the completion of work, the handling or execution of a task.

Hodgetts and Kuratko, in assessing performance must have five basic characteristics: (1) it relates directly to the task of the person and measures his ability to perform the task, (2) complete, by measuring all important aspects, (3) (4) based on the desired performance standard, (5) designed to know one's strengths and weaknesses and then to explain why it happened and how to overcome it [8].

In the context of teachers, performance is often linked to questions, is it true that the teacher is working in the classroom, what the teacher has done for the student, what the teacher has done for the school, what contributions teachers give to the school and government, and some other questions related to teacher work performance.

Based on the above descriptions illustrate the importance of teacher performance to achieve maximum learning outcomes, so it can be concluded that the high quality of education is strongly influenced by the high or low performance of teachers.

The performance of the teacher can be seen from his sense of responsibility in carrying out his mandate, his profession, and his sense of moral responsibility on his life. All that will be visible to his obedience and loyalty in carrying out his teacher's duties in the classroom and his educational duties outside of the classroom. This attitude will give consequences of his sense of responsibility to prepare all teaching equipment before implementing the learning process, including methods, teaching materials, media, as well as technique and instrument assessment tool.

Meanwhile, the assessment of teacher performance, technically Ahmad Sudrajad proposed three steps, namely: (1) Classroom Observation, (2) Checking work program, especially lesson plans, and (3) Conducting data validation through triangulation of researchers / verifiers.

For teachers who already have a certificate of education will earn income above the minimum living cost and social welfare guarantees. Ironically, however, the government's efforts will be wasted when the performance of certified teachers (professional teachers) does not improve it is compared to teacher performance before being certified. This can happen if after being certified, the teacher's performance decreases because he/she feels no longer assessed, and there is no sanction. Therefore it is necessary to evaluate the performance of teachers who have been certified in a sustainable manner.

Certification as a symbol of professionalism that will be on improving welfare is a fresh breeze for teachers and prospective teachers. Certification makes the profession of teachers as a profession that can no longer be underestimated, this of course spur teachers to love their profession, and with the teacher's love of his profession will encourage him to commit to work better, but in fact there are still teachers certified that has a low performance and vice versa that is the discovery of teachers who have not certified but have a good teacher performance.
Indonesian Teacher Organization (PGRI) in its survey of 28 provinces in Indonesia shows that teacher performance is still low, even indicated that teacher's motivation has been lowered in planning and implementing learning compared to other teachers who have not passed the certification (2009). The results of research on the impact of certification on teacher performance improvement involving 840 teachers in 21 provinces spread across 84 districts indicate that passion in improving educational qualifications, the ability to purchase certification support books, subscribe to newspapers / journals, computer use habits and participation in following training/seminars, making teaching materials, engaging in professional activities, to research and write scientific papers show an increasing trend (2011). The low quality of education in general, indicated by the existence of certified teachers who are negligent in carrying out their teacher duties, and vice versa the existence of non-certification teachers who perform well. This fact leads to the assumption that there is no difference between certified and uncertified teachers.

The word Commitment is derived from the Latin language Committee, to connect, entrust the state of being bonded or emotionally impelled, i.e. a belief that binds so firmly as to impose a whole conscience and then move behavior toward the direction it believes [2]. In Big Indonesian Dictionary (KBBI), commitment is an agreement (attachment) to do something contract.

Professionals derived from the word Profession (Profession) defined as a typical type of work that requires knowledge or expertise or science used in applications to connect with other people, agencies or institutions. According to Sardiman, the profession is defined as a work that requires continuing education in science and technology that is used as a basic tool to be implemented in a variety of useful activities.

According to M. Jasin in Yunus Namsa, the profession is a field in which the job requires scientific techniques and procedures, has a dedication and how to address the field that is oriented service of the expert. Profession is also defined as a position or a specific job that requires knowledge and special skills gained from intensive academic education. Thus, the profession is a job or position that requires a certain skill. Professions can be interpreted as a specific job or position that requires special knowledge and skills gained from incentive academic education [6].

Based on some opinions can be concluded that the profession is a job or expertise that becomes a source of income by requiring intellectual competence, attitudes and skills that are processed through academic process of education.

According to Pitrawati, commitment to work is defined as the psychological relationship between a person and his work based on an affective reaction to the job. Mayer et al., In Kusmaryani, mentions three components of commitment to work developed from organizational commitment are (1) affective commitment. (2) Commitment of calculus (continuity commitment) (3) Normative commitment (normative commitment) [4]. 
In relation to the performance of a teacher is certainly strongly influenced by one's commitment in carrying out his professional duties. According to Cascio, in Kusmaryani, most people would assume that the level of individual performance is affected by performance-related conditions [4]. Teachers who have a strong attachment to their work mean that the teacher has a high commitment.

From the above description it can be understood that the certification status of a teacher will foster a sense of love, responsibility and high desire to have / maintain it so as to give birth a high commitment in carrying out the tasks of the profession and automatically will positively affect the performance.

Based on the focus of the problems mentioned above, then the formulation of the problem in this research will be:

1. Is there any difference in performance between teachers who have been certified and teachers who have not been certified in Madrasah Samarinda city?

2. Is there any effect of interaction between certification status and professional commitment to teacher performance in Madrasah Tsanawiyah of Samarinda city?

3. Is there any difference in performance between highly committed certified teachers and highly committed noncertified teachers in Madrasah Tsanawiyah in Samarinda city?

4. Is there any difference in performance between lowly committed certified teachers and highly committed noncertified teachers at Madrasah.

\section{Methodology}

The approach used in this study is a comparative quantitative approach with ex post-facto research method and experimental treatment design by level $2 \times 2$. Target Population is 613 teachers who are spread on 9 sub-districts in 32 Madrasahs. Sampling on the group of teachers with Multistage sampling of 120 people is certified and 120 teachers are noncertified

In the certified and uncertified group of teachers are given a questionnaire to identify teachers with high professional commitment and teachers who are professionally low. Furthermore, the results of the questionnaire of professional commitment from each of 120 people are divided as many as 25 people who are committed to high professions and 25 teachers who are committed to low professions so that the data is divided into 4 groups of teachers who are committed to the professional profession (A1B1), certified teachers who are professionally low (A1B2), highly committed non-certification teachers (A2B1) and non-certified teachers with low professions (A2B2)., Table I.

The data collection is done through the spreading of questionnaires in the form of Likert scale with five alternative answers with details: Always $=5$, Often $=4$, Sometimes $=3$, Rarely $=2$, and never $=1$.

This study uses two instruments, namely instrument to measure teacher's performance and instrument to measure teacher's professional commitment, while certification status is not given instrument because it has been classified based on the ownership status of educator certificate. Instrument Validation is done by using Product Moment Test with t-Test, and Test of Reliable using.

Data were analyzed by two-way ANAVA, normality test of data using Liliefors test while homogeneity test data using Bartlett Test and F test. Comparative data test between cells using T-Dunnet test and Turkey Test.

TABLE I. DESIGN RESEARCH TREATMENT BY LEVEL 2X2 EFFECT OF TEACHER CERTIFICATION AND TEACHER PROFESSIONAL COMMITMENT TO TEACHER

\begin{tabular}{|l|l|l|}
\hline \multirow{2}{*}{$\begin{array}{l}\text { Commitment } \\
\text { Teacher Professions } \\
(\mathrm{B})\end{array}$} & $\begin{array}{l}\text { Status } \\
\text { Teacher Certification } \\
(\mathrm{A})\end{array}$ \\
\cline { 2 - 3 } & (A1) & (A2) \\
\hline (B1) & Yt(A1B1) & Yt(A2B1) \\
\hline (B2) & Yt(A1B2) & Yt(A2B2) \\
\hline Total & Yt(A1) & Yt(A2) \\
\hline
\end{tabular}

\section{RESULTS AND DISCUSSION}

The result of normality data test is done by using Lilliefors test with alpha value $(\alpha=0,05$ or $\alpha=0,01)$ with test criteria that is said to be normally distributed if Lcount $<$ LTable. Normality test for all data groups used in this study shows Lcount $<$ LTable so that data is normally distributed. as shown in the following Table II.

TABLE II. SUMmary OF DATA NORMALITY TEST RESUlts

\begin{tabular}{|l|l|l|l|l|l|}
\hline Data & Number of & $\mathrm{L}_{\text {Count }}$ & \multicolumn{2}{|l|}{$\mathrm{L}_{\text {Table }}$} & Conclusion \\
\cline { 4 - 5 } Group & Samples & & 0,05 & 0,01 & \\
\hline $\mathrm{Y}_{\mathrm{t}(\mathrm{A} 1)}$ & 120 & 0,0585 & 0,081 & 0,094 & Normal \\
\hline $\mathrm{Y}_{\mathrm{t}(\mathrm{A} 2)}$ & 120 & 0,0679 & 0,081 & 0,094 & Normal \\
\hline $\mathrm{Y}_{\mathrm{t}(\mathrm{A} 1 \mathrm{~B} 1)}$ & 25 & 0,1458 & 0,173 & 0,206 & Normal \\
\hline $\mathrm{Y}_{\mathrm{t}(\mathrm{A} 2 \mathrm{~B} 1)}$ & 25 & 0,1657 & 0,173 & 0,206 & Normal \\
\hline $\mathrm{Y}_{\mathrm{t}(\mathrm{A} 1 \mathrm{~B} 2)}$ & 25 & 0,1286 & 0,173 & 0,206 & Normal \\
\hline $\mathrm{Y}_{\mathrm{t}(\mathrm{A} 2 \mathrm{~B} 2)}$ & 25 & 0,0699 & 0,173 & 0,206 & Normal \\
\hline
\end{tabular}

Testing homogeneity of variance from four groups in this study using Bartlett Test. the result of the calculation as stated in the table above shows that the value of $\mathrm{x} 2$ count is 1.1052 whereas x2Table is 7,815 $(\alpha=0,05)$ and $11,345(\alpha=0,01)$. Thus it can be concluded that the variance of the data is homogeneous because the value of $x 2$ count $<\times 2$ Table. Recapitulation of the result of homogeneity of data is presented in the following Table III.

TABLE III. RECAPITULATION OF HOMOGENEITY VARIANCE FOR FOUR DATA GROUPS.

\begin{tabular}{|l|l|l|l|l|}
\hline $\begin{array}{l}\text { Four Data } \\
\text { Groups }\end{array}$ & $\mathrm{X}_{\text {Count }}^{2}$ & $\mathrm{X}_{\text {Count }}^{2}$ & Conclusion \\
\cline { 3 - 4 } & & 0,05 & 0,01 & \\
\hline $\begin{array}{l}\mathrm{Y}_{\mathrm{t} \text { (A1B1) }}, \mathrm{Y}_{\mathrm{t}} \\
(\mathrm{A} 2 \mathrm{~B} 1), 1052\end{array}$ & 7,815 & 11,345 & Homogen \\
\hline $\begin{array}{l}\mathrm{Y}_{\mathrm{t} \text { (A1B2) }}, \mathrm{Y}_{\mathrm{t}} \\
(\mathrm{A} 2 \mathrm{~B} 2)\end{array}$ & & & & \\
\hline
\end{tabular}

Furthermore, to find out whether the two groups between certified teachers and non-certified teachers have homogeneous data used $\mathrm{F}$ test with the calculation results show that the 
variance data of both groups is homogeneous because the value of each Fcount $<$ FTable.

TABLE IV. RECAPITULATION OF HOMOGENEITY CALCULATION RESULTS BOTH GROUPS' VARIANCE USING F TEST

\begin{tabular}{|c|c|c|c|c|}
\hline \multirow{2}{*}{$\begin{array}{l}\text { Four Data } \\
\text { Groups }\end{array}$} & \multirow[t]{2}{*}{$\mathrm{F}_{\text {Count }}$} & \multicolumn{2}{|c|}{$\mathrm{F}_{\text {Table }}$} & \multirow[t]{2}{*}{ Conclusion } \\
\hline & & 0,05 & 0,01 & \\
\hline $\begin{array}{l}Y_{t(A 1 B 1)} \\
Y_{t(A 2 B 1)}\end{array}$ & 1,333 & 1,98 & 2,66 & Homogen \\
\hline $\begin{array}{l}Y_{t(A 1 B 2)} \\
Y_{t(A 2 B 2)}\end{array}$ & 1,379 & 1,98 & 2,66 & Homogen \\
\hline
\end{tabular}

The results of hypothesis testing obtained through testing the hypothesis of the effect of teacher certification and profession commitment to teacher performance in the following table:

TABLE V. RESUlTS ANOVA CALCULATION OF THE EFFECT OF TEACHER CERTIFICATION AND TEACHER PROFESSIONAL COMMITMENT TO TEACHERS' PERFORMANCE.

\begin{tabular}{|l|l|l|l|l|l|l|}
\hline Source & JK & $\mathrm{dk}$ & $\mathrm{RJK}$ & $\mathrm{F}$ & \multicolumn{2}{|l|}{$\mathrm{F}_{\text {Table }}$} \\
\cline { 5 - 8 } \\
Variance & & & & Count & $\begin{array}{l}\alpha= \\
0,05\end{array}$ & $\begin{array}{l}\alpha= \\
0,01\end{array}$ \\
\hline Factor A & 259 & 1 & 259 & 6,11 & 3,94 & 6,90 \\
\hline Factor B & 83463 & 1 & 83463 & 19,85 & 3,94 & 6,90 \\
\hline $\begin{array}{l}\text { Interaction } \\
\text { A x B }\end{array}$ & 116 & 1 & 116 & 27,5 & 3,94 & 6,90 \\
\hline In (error) & 4070 & 96 & 42,4 & & & \\
\hline Total & 88958 & 99 & & & & \\
\hline
\end{tabular}

The first hypothesis test was performed using two way anova with statistic hypothesis which tested is Ho: $\mathrm{YtA}_{1} \mathrm{YtA}_{2}$ compared with $\mathrm{Hi}: \mathrm{YtA}_{1} \mathrm{YtA}_{2}$. Test results show that $\mathrm{F}_{\text {count }}$ $6.11 \mathrm{~F}_{\text {table }} 3.94$ at $\alpha=0.05$. Then the null hypothesis is rejected and another hypothesis stating that "there is a difference in teacher performance that has been certified and that has not been certified" is accepted. The average performance of teachers who have been certified is 147.88 while the average performance of teachers who have not certified is as low as 142.68 , this indicates that the performance of teachers who have certification is higher than the performance of teachers who have not certified.

Testing of second hypothesis with hypothesis of statistic that is $\mathrm{H0}$ : $\mathrm{Yt}$ (interaction $\mathrm{AB}$ ) $=0$ and $\mathrm{Hi}$ : $\mathrm{Yt}$ (interaction $\mathrm{AB}$ ) 0 . Test result show that $\mathrm{F}_{\text {Count }} 27,5 \mathrm{~F}_{\text {tabel }} 3,94$ at $\alpha=0,05$ and 6,90 at $\alpha=0.01$ so that the null hypothesis is rejected while the alternative hypothesis states that "there is an interaction effect between certification status and professional commitment to the performance of Madrasah Tsanawiyah teachers" is accepted.

To see clearly the interaction of certification status with professional commitment, it is shown in the estimation of the interaction line between the two variables. On the $\mathrm{X}$ axis is determined as a professional commitment variable $\left(\mathrm{B}_{1}\right)$ and low profession commitment $\left(\mathrm{B}_{2}\right)$, while on the $\mathrm{Y}$ axis as treatment variables are certified teachers $\left(A_{1}\right)$ and noncertification teachers $\left(A_{2}\right)$ in the following figure:

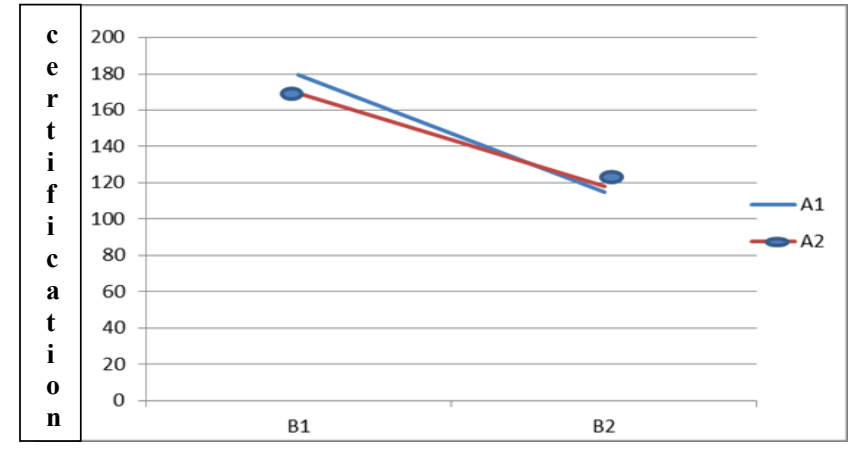

Fig. 1. Interaction between Certification Status and Teacher Profession Commitment

Testing of hypothesized difference of certified teacher performance (A1) and non-certification (A2) with high professional commitment (B1) and low profession commitment in third and fourth hypothesis using comparative test between cells (simple effect test) t-Dunnet test. Results testing is presented in the following table:

TABLE VI. SUMMARY OF T-DUNNET TEST RESUlT RESULTS EFFECT OF TEACHER CERTIFICATION STATUS WITH TEACHER PROFESSION COMMITMENT TO TEACHER PERFORMANCE

\begin{tabular}{|l|l|l|l|l|}
\hline No & DataGrouf & $\mathrm{T}_{\text {Count }}$ & $\mathrm{t}_{\text {Table }}$ & \\
\cline { 4 - 5 } & & & $\alpha=0,05$ & $\alpha=0,01$ \\
\hline 1 & $\begin{array}{l}\mathrm{Y}_{\mathrm{t}(\mathrm{A} 1 \mathrm{~B} 1} \\
\text { andY }\end{array}$ & 5,36 & 1,658 & 2,358 \\
\hline 2 & $\begin{array}{l}\mathrm{Y}_{\mathrm{t}(\mathrm{A} 1 \mathrm{~A} 2 \mathrm{~B} 2} \\
\text { andY }\end{array}$ & $-1,87$ & 1,658 & 2,358 \\
\hline
\end{tabular}

Results of testing the third hypothesis with statistical hypothesis $\mathrm{H}_{0}$ : Yt $\left(\mathrm{A}_{1} \mathrm{~B}_{1}\right) \mathrm{Yt}\left(\mathrm{A}_{2} \mathrm{~B}_{1}\right)$. And $\mathrm{H}_{\mathrm{i}}$ : $\mathrm{Yt}\left(\mathrm{A}_{1} \mathrm{~B}_{1}\right) \mathrm{Yt}$ $\left(\mathrm{A}_{2} \mathrm{~B}_{1}\right)$. The results show that tcount $=5.36$ ttabel 1.658 at $\alpha=$ 0,05 and 2,358 at $\alpha=0,01$. So the null hypothesis is rejected and the alternative hypothesis stating "there is a difference in performance in teachers who have high professional commitment among teachers who have certification with teachers who have not certified" is accepted. The average performance of certified teachers is 179.54 while the average performance of teachers who have not certified is 169.32 . Of the averages indicate that the performance of teachers who have high professional commitment in certified teachers is on average higher than teachers who have not certified.

Testing the fourth hypothesis with statistical hypothesis: $\mathrm{H}_{0}$ : Yt $\left(\mathrm{A}_{2} \mathrm{~B}_{1}\right) \mathrm{Yt}\left(\mathrm{A}_{2} \mathrm{~B}_{2}\right)$. And Hi: Yt $\left(\mathrm{A}_{2} \mathrm{~B}_{1}\right)$ Yt $\left(\mathrm{A}_{2} \mathrm{~B}_{2}\right)$. The result of test by using t-Dunnet test shows that tcount $=$ 1,87 ttabel $-1,658$ at $\alpha=0,05$ then $\mathrm{Ho}$ is rejected and $\mathrm{Hi}$ accepted so hence the influence of certification on teacher performance that is low commitment to non-certification teacher is higher of certified teachers.

The results of this study is the result of testing of all hypotheses that consists of four hypotheses that all four reject the null hypothesis (Ho) and accept the alternative hypothesis (Hi). The results of hypothesis testing on Performance differences between certified and uncertified teachers show that certified teachers are more performance than those of 
uncertified teachers. In fact, a certified teacher does not necessarily receive a professional allowance, but to obtain the professional allowance teachers must fulfill their obligations which are of course directly related to the teacher's performance. Every certified teacher is required to teach at least 24 to 40 hours face to face in a week, this condition is mandatory for the teacher and if not fulfilled then the professional allowance is constrained to be paid, so this of course affects the performance.

In addition to the obligations that must be met, certified teachers are also teachers who have experience in their respective fields and also on average have taken the path of education and professional training teachers (PLPG) so that it has been provided with the back- activities that are directly related to the improvement of teachers' abilities.

Based on the above descriptions indicates that certified teachers are conditioned to fulfill their professional obligations while at the same time having a strong impetus to have higher performance than uncertified teachers.

Certification is a professional indicator of a teacher because with this status a teacher is entitled to get a professional allowance amounting to one time salary, this is considered a factor that affects the performance of a teacher. However, this performance improvement may also occur due to other factors. One factor that is considered very influential on the performance of a person is because of the love of the job so that trigger him to exert all efforts as much as possible in doing the profession. A love of the profession makes a person build a commitment within himself to provide something best for his profession. Commitment of the profession also raises one's loyalty to the tasks of his profession so as to earnestly and maximally for the benefit of his profession.

The result of hypothesis testing shows that certified teachers with high teacher profession commitment have higher performance compared to non-certification teachers even though they have high profession commitment. This is because in addition to already having a high commitment to the profession, certified teachers are also prosecuted and conditioned by binding rules in the process of granting benefits directly related to their performance as professional teachers. In addition, the existence of professional allowance received by teachers will make the teacher more love his profession and there is a feeling of fear of losing so as to maintain himself as a professional teacher.

Unlike the uncertified teachers, even though they have a high commitment to their profession, they are not yet fully conditioned to fulfill the obligations that teachers certification should meet. In non-certification teachers the rules used are still relatively general and are recommended since there is no obligatory obligation. Thus the performance of certified teachers is higher than the performance of non-certified teachers.

The results of hypothesis testing on teachers who have low teacher profession commitment show different things with the results of testing on teachers who have high professional commitment. Certified teachers with low professional commitment have lower performance compared to non- certification teachers' performance. This happens because the certified teachers some of them approaching the age of retirement / pension with the physical condition that has decreased so that its performance becomes low if the commitment of the profession is also low. Unlike noncertification teachers although on the one hand their professional commitment is low but their young age, stamina is still good and there is encouragement for them to be included in the certification quota so as to encourage the improvement of their performance.

The commitment of the profession is a firm attachment in a person to his duties and obligations that can encourage him to always try to do his best for his profession voluntarily. Love of this profession can grow and develop in itself because of the factors that influence it both from within (internal) and from outside the (external). Love of the profession of teachers also arise because this profession is able to provide adequate salary and good social status as the fulfillment of life needs.

The performance of certified teachers is lower than that of non-certified teachers although both have low professional commitment. A strong desire for non-certification teachers to get the opportunity to follow the certification program becomes the main motivation in mobilizing all efforts and capabilities so that their performance is better. Unlike the case with certified teachers who have low profession commitment, the teachers are just trying to fulfill their obligations in quantity alone without paying attention to the quality of their learning, consequently their performance is relatively low. Based on the above explanation can be understood that the performance of teachers- certified teachers with low professional commitment have lower performance compared to the performance of lowperforming non-certified teachers.

\section{CONCLUSION}

There is some difference in performance between certified teachers and uncertified teachers, where certified teachers have higher performance than uncertified teachers. There is an effect of interaction between certification status and teacher professional commitment to teacher performance, meaning that teacher profession commitment and certification status influence each other on teacher performance. Certified teachers who are committed to higher professions have higher performance than teachers who commit profession high but not yet certified. Certified teachers who are committed to lower professions have lower performance than uneducated teachers who are also proficient in low professions.

The results of the study generally indicate that certification status and teacher professional commitment have a positive effect on teacher performance. Efforts to improve the performance of certified teachers can be done by improving the competence of teachers who have been certified namely: (a) Education and training, and (b) Participation in the teacher profession Association. Education and training is a requirement for every teacher, which can be implemented in Madrasah or schools through In House Training (IHT) activities that can provide refresh and were additional scientific input. Participation in the profession of teachers also increases the competence, teachers can synergize among the same teachers 
so as to provide opportunities to exchange information, discussion seeking solutions from learning problems. Continual refreshment so that teachers obtain additional information and knowledge that will improve their teacher competencies that will also impact on teacher performance improvement.

High profession commitment will affect the performance and commitment of the profession, the improvement can be done is a personal approach that is planting moral values and a sense of responsibility to each teacher as an obligation to the profession. Against external factors, may arise as a result of the influence of the surrounding environment, with a positive professional work environment. The low commitment of a teacher can also arise because of the lack of love of the teacher profession, causing low performance.

\section{REFERENCES}

[1] Achmad S. Ruky, Performance Management Sistem, (Jakarta: PT. Gramedia PustakaUtama, 2006).

[2] Fauzan Akhmad, Professional Teacher Commitment, Article, p. 1, downloaded November 2014.
[3] Harvey Robert Bruch Bowin D. Human Resource Management, New York: McGraw-Hill, 1996

[4] Kusmaryani, Commitment to Employment and Performance of Advisor Teachers in Bantul District (Journal of Research and Development of DIY Provincial Government, Vol. 1.No. 1, tahun 2009,

[5] Muslich Masnur, Teacher Certification Towards Educator Professionalism, (Jakarta: BumiAksara, 2007).

[6] Namsa M.Yunus, The New Gait for Indonesian Teachers Profession Insights Methodology Islamic Teaching, Jakarta : PT Gramedia, 2007

[7] Paul Hersey, Kenneth Blanchard, and Dewey E. Johnson, Managing Organizational Behavior: Utilizing Human Resources, (New Jersey: Prentice Hall, Inc, 1996).

[8] Richard M. Hodgetts\& Donald F. Kuratko, Management, (San Diego: Harcourt Brace Jovanovich Publischers, 1988).

[9] Stephen P. Robbins, Managing Today (New Jersey: Prentice-Hall International, Inc, 1997).

[10] Stephen P. Robbins, Essentials of Organisation Behavior( NewJersey:Prentice Hall, Inc, 2005)

[11] Tika Muh. Pambudu, Organizational Culture and Corporate Performance Improvement, (Jakarta: PT Bumi Aksara, 2000). 